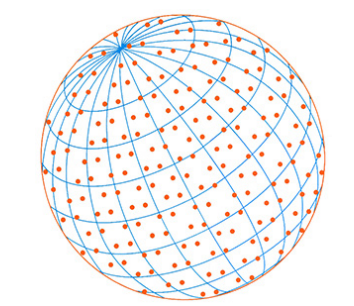

Aerosol and Air Quality Research

\title{
Source Impact Analysis Using Char-EC/Soot-EC Ratios in the Central Indo-Gangetic Plain (IGP) of India
}

\author{
Manisha Mishra, U.C. Kulshrestha*
}

School of Environmental Sciences, Jawaharlal Nehru University, New Delhi - 110067, India

\section{ABSTRACT}

This study measured the carbonaceous aerosols in the atmospheric fine particulate matter (fPM; dia. $<2.5 \mu \mathrm{m}, n=102$ samples) above an urban location (Prayagraj) on the central IndoGangetic Plain (IGP) for 1 year (December 2016-November 2017). During the study period, the fPM mass concentrations exhibited very high variability, ranging from 22 to 367 (avg. \pm SD: 149 $\pm 87) \mu \mathrm{g} \mathrm{m}^{-3}$, and approximately $40 \%$ of the annual average consisted of carbonaceous aerosols (organic carbon [OC], water-soluble $O C$ [WSOC], and elemental carbon [EC]). Furthermore, several diagnostic ratios (EC/fPM, OC/EC, char-EC/soot-EC, and WSOC/OC) indicated that the characteristics of the carbonaceous aerosols significantly differed between seasons, with emission sources, seasonal meteorology, and atmospheric chemistry driving the variation in abundance. Specifically, our trajectory analysis revealed an association between northwesterly air masses originating in northwestern India and higher concentrations of fPM and carbonaceous aerosols at the study site, which mainly occurred during the post-monsoon season and winter. However, anthropogenic emissions from local sources dominated the fPM and carbonaceous aerosols in summer and the monsoon season, during which we also observed the influence of air masses of mixed (continental/marine) origin. To identify the sources of the carbonaceous aerosols and evaluate their contributions, we analyzed the char-EC/soot-EC ratio in combination with the OC/EC ratio. Cross plots of these ratios identified biomass burning and fossil-fuel combustion as the largest sources during winter and the post-monsoon season, and summer and the monsoon season, respectively. Our results demonstrate the advantages of utilizing the char-EC/soot-EC ratio rather than the $\mathrm{OC} / \mathrm{EC}$ ratio as a tracer of these two sources in the IGP region.

Received: November 13, 2020

Revised: May 17, 2021

Accepted: June 8, 2021

${ }^{*}$ Corresponding Author:

umeshkulshrestha@gmail.com

\section{Publisher:}

Taiwan Association for Aerosol Research

ISSN: $1680-8584$ print

ISSN: 2071-1409 online

Copyright: The Author(s). This is an open access article distributed under the terms of the Creative Commons Attribution License (CC BY 4.0), which permits unrestricted use, distribution, and reproduction in any medium, provided the original author and source are cited.

Keywords: Indo-Gangetic Plain, Carbonaceous aerosols, OC/EC ratio, Char-EC/Soot-EC ratio, Secondary organic aerosol

\section{INTRODUCTION}

Carbonaceous aerosols, viz., organic aerosol (OA) and elemental carbon (EC), have been observed as one of the ubiquitous constituents in the atmosphere, playing an active role in environmental health and climate (Penner et al., 1991; Haywood and Boucher, 2000; Jacobson, 2001; Ramanathan et al., 2001; Tiwari et al., 2016; Pal et al., 2018). Depending on the size range of particulates, sometimes a large portion of their total mass is comprised of the carbonaceous species. Furthermore, contributing negligibly in remote areas, they can contribute up to $80 \%$ by mass of fine aerosols $\left(<\mathrm{PM}_{2.5}\right.$ ) over the polluted urban region (Saxena and Hildemann, 1996; Putaud et al., 2004; Hand et al., 2012; Brooks et al., 2019). Organic aerosols can be produced directly by their emissions sources like biomass/biofuel burning (BB) and fossil-fuel combustion (FFC) (referred to as primary organic aerosol [POA]) as well as can be formed through physicochemical transformations (widely referred to as secondary organic aerosol [SOA]) (Finlayson-Pitts and Pitts, 2000; Gelencsér, 2004; Rajput et al., 2014). A fraction of organic carbon (OC) is watersoluble and referred to as water-soluble OC (WSOC). The utility of WSOC to serve as a surrogate 
for SOA and/or their origin from BB emission $(\leq 20 \%)$ has been suggested previously (Sannigrahi et al., 2006; Snyder et al., 2009; Singh et al., 2017). In sharp contrast to OC, EC is primary in origin and emitted from incomplete combustion activities such as biomass/biofuel burning, vehicular exhausts, and coal combustion (Gelencsér, 2004; Jimenez et al., 2009).

Unlike subject to alteration of OC/EC ratio under atmospheric aging, the char-EC/soot-EC ratio has been found relatively stable, and therefore suggested previously to serve as a robust tracer of their source origin (Han et al., 2007, 2010). Han et al. (2007, 2009, 2010, 2016) have extensively investigated the ratio of char-EC/soot-EC for source identification at different locations in China. However, most of the previous studies conducted over the Indian region have found the utility of OC/EC ratio (and sometimes molecular tracers) to characterize the BB and FFC emissions owing to higher contribution of OC from its predominant source of BB emission (Ram and Sarin, 2010; Pachauri et al., 2013; Rajput and Sarin, 2014; Rajput, 2018; Singh et al., 2018). Using various receptor modeling tools, source apportionment studies have revealed that BB and FFC contribute up to $60 \%$ of fine aerosols in urban areas of the upper IGP region (Singh et al., 2017; Jain et al., $2021 a, b)$. In view of the above-mentioned studies, we decided to investigate the plausibility of identifying sources based on char-EC/soot-EC in conjunction with OC/EC ratio at a less explored site located in the Indo-Gangetic Plain (IGP). The present study assesses the atmospheric abundance of carbonaceous aerosols (OC, WSOC, char-EC, soot-EC) in fine particulate matter (fPM, i.e., dia. $<2.5 \mu \mathrm{m}$ ) over a period of 1 year from an urban site at Prayagraj located in the central part of IGP. One of the major objectives of this study is to assess the suitability of char-EC/soot-EC ratio in conjunction with OC/EC for tracing out their emissions from BB and FFC sources in IGP region. Furthermore, concentration-weighted trajectories (CWTs) and cluster analysis were also performed to assess the dominant source region(s) of carbonaceous aerosols that impacted the receptor site during different seasons.

\section{METHODOLOGY}

\subsection{Description of Sampling Location}

The sampling site Prayagraj $\left(25^{\circ} 54^{\prime} \mathrm{N}, 81^{\circ} 85^{\prime} \mathrm{E}, 98 \mathrm{~m}\right.$ a.s.I.) is situated in the central part of IndoGangetic Plain. The Prayagraj is considered a holy city owing to several temples and confluence point of rivers, the Ganga and the Yamuna (Fig. 1). The city covers an area of $70.5 \mathrm{~km}^{2}$ and the district has a population density of 1,086 persons $\mathrm{km}^{-2}$ (as per the census 2011). Over 100 million people from various states of India gather at Prayagraj city in the months of January and February to celebrate the festival of Kumbh. The visible major anthropogenic sources of air pollutants in
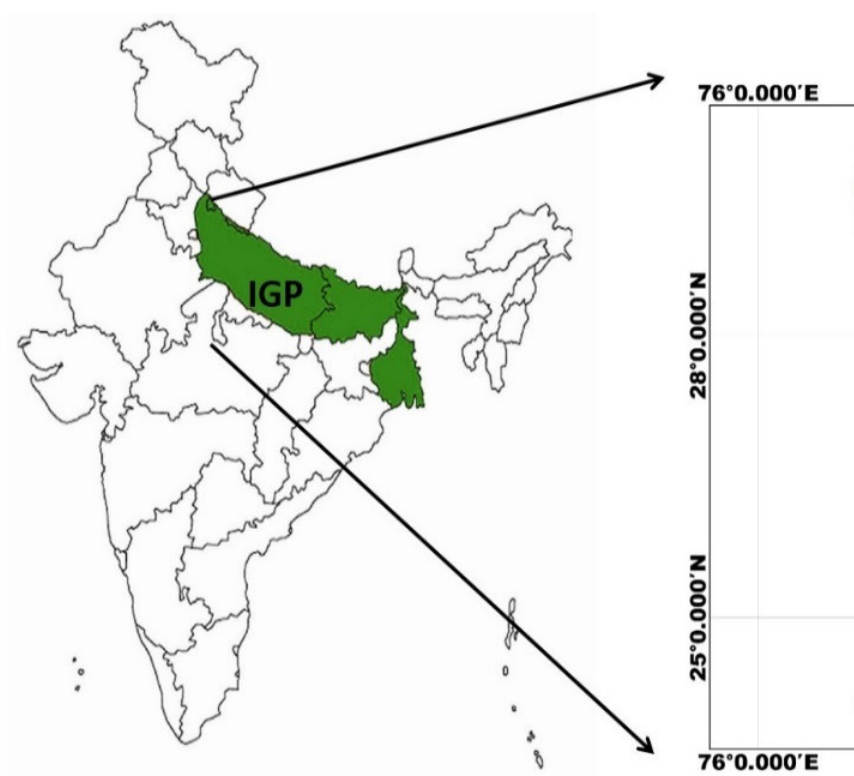

$8^{\circ} \mathbf{0 . 0 0 0} E$ $8^{\circ} 0.000^{\prime} E$
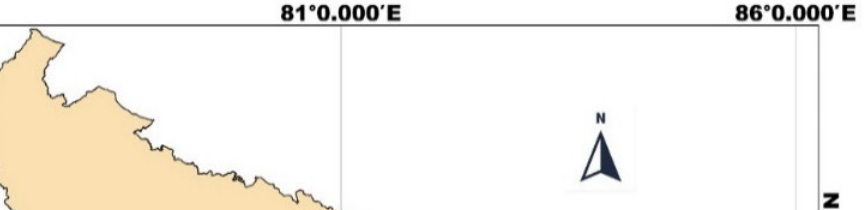

Fig. 1. Figure showing sampling location at Prayagraj in the central region of Indo-Gangetic Plain (IGP). 
the city include coal-powered thermal power plants and vehicular emissions (both gasoline- and diesel-based). In the outskirts of the city, biofuel burning is carried out for cooking purpose around the year and also for heating purpose during the winter months. Furthermore, from October through February (post-monsoon and wintertime), under the northwesterly wind system, the receptor site is located downwind $(\sim 1000 \mathrm{~km})$ of the source region of major agricultural biomass-burning emissions (Rajput and Sarin, 2014).

\subsection{Meteorology}

The IGP region can be categorized under a humid subtropical climate. The annual mean temperature of Prayagraj is about $26^{\circ} \mathrm{C}$. January is recorded as the coldest and May as the warmest month (as per data set from the Indian Meteorological Department [IMD]; Fig. 2). Depending on the prevailing meteorology, four seasons have been studied as winter (December-February), summer (March-June), monsoon (July-September) and post-monsoon (October-November). Except for summer months, relative humidity usually remains more than $50 \%$ over the region. Annual average precipitation centers at $\sim 900 \mathrm{~mm}$, of which about $70 \%$ occurs during the monsoon period. In terms of wind speed, post-monsoon and winter seasons are characterized by calm weather condition. Furthermore, a shallower boundary layer height restricts the dispersion of pollutants, and thus, post-monsoon and winter seasons are associated with usually polluted events reflected by the lowest visibility.

\subsection{Sampling and Chemical Analysis}

Aerosol (hereinafter represented as fine particulate matter [fPM] with dia. $<2.5 \mu \mathrm{m}$ ) sampling was conducted using a customized low-volume sampling (LVS) unit which was operated at a continuous flow rate of $30 \mathrm{~L} \mathrm{~min}^{-1}$ on a pre-baked $47 \mathrm{~mm}$ Pallflex ${ }^{\circledR}$ Tissuquartz 2500QAT-UP microfiber filters. Such sampling units have been used to collect fPM in previous studies (Leck

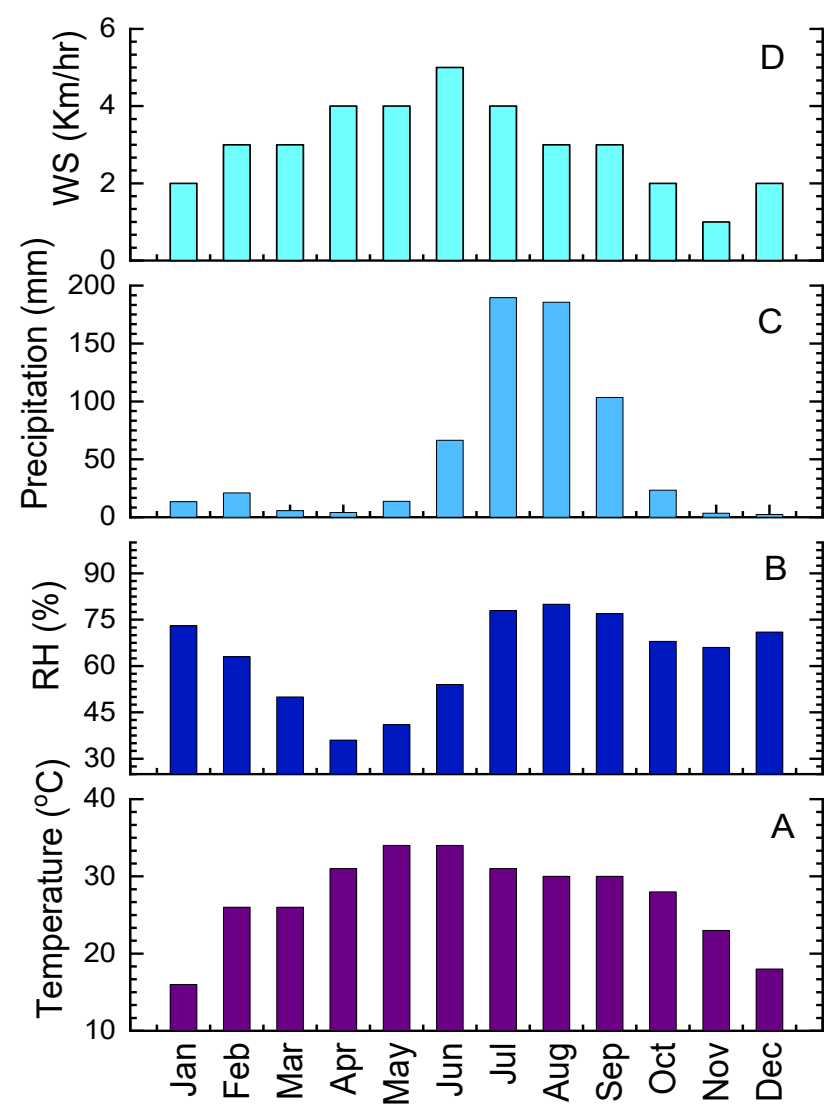

Fig. 2. Typical meteorological parameters (monthly average) during the study period over IGP (source: www.imd.gov.in). 
and Persson, 1996; Granat et al., 2002; Tiwari and Kulshrestha, 2019). 8-h continuous sampling (09:00-17:00 h) was conducted twice a week (almost on every third day) at the sampling site starting from 1 December 2016-30 November 2017. The sampler was mounted $1.5 \mathrm{~m}$ above the surface on the terrace of a building. In order to determine the fPM mass loading, each filter was kept in a desiccator (partially filled with activated silica gel) for $\sim 24 \mathrm{~h}$ before measuring initial and final weights using a high-sensitivity microbalance. Filter samples were stored properly at $\sim 4^{\circ} \mathrm{C}$ in a deep-freezer prior to the analysis. Field blanks were also collected during each month to assess the quality control of the data. The method detection limit (MDL) of the sampler was observed to be $0.54 \mu \mathrm{g} \mathrm{m}^{-3}$ with the uncertainty (as calculated from replicate samples) in the range of $8-10 \%$. A total of 102 samples have been collected from the study site over the 1-year period covering all four seasons, viz., winter, summer, monsoon, and post-monsoon.

Desert Research Institute (DRI) Carbon Analyzer (Model 2001A) has been utilized to quantify the OC and EC using Interagency Monitoring of PROtected Visual Environments (IMPROVE-A) protocol. The thermal/optical reflectance (TOR) method was used for the determination of OC and EC (Chow et al., 2007; Han et al., 2007). A filter punch of $0.5 \mathrm{~cm}^{2}$ area was taken from the sample and placed on the analyzer's sample port. Due to step-wise heating of sample, differential volatilization of $\mathrm{OC}$ in four fractions occurs: OC1 at $120^{\circ} \mathrm{C}, \mathrm{OC} 2$ at $240^{\circ} \mathrm{C}, \mathrm{OC} 3$ at $480^{\circ} \mathrm{C}$ and $\mathrm{OC} 4$ at $580^{\circ} \mathrm{C}$ in a pure $\mathrm{He}$ condition whereas three fractions of $\mathrm{EC}$ volatilizes at higher temperatures: $\mathrm{EC} 1$ at $580^{\circ} \mathrm{C}, \mathrm{EC} 2$ at $740^{\circ} \mathrm{C}$ and $\mathrm{EC} 3$ at $840^{\circ} \mathrm{C}$ in a mixture of $98 \% \mathrm{He}+2 \%$ oxygen. Pyrolyzed organic carbon (OP) is determined using the optical method as the reflectance reaches its initial value soon after the injection of mixture gas (at $580^{\circ} \mathrm{C}$ ). This procedure corrects the overestimation of EC through continuous monitoring of reflectance during analysis. While the volatilization of $\mathrm{OC}$ occurs in the presence of pure $\mathrm{He}$ and catalyst $\mathrm{MnO}_{2}$ at lower temperatures, $\mathrm{EC}$ is evolved in the presence of $\mathrm{He}$ gas and $2 \%$ oxygen at higher temperatures for their final conversion into $\mathrm{CO}_{2}$. The difference between EC1 and OP is calculated as char-EC and the addition of EC2 and EC3 is defined as soot-EC (Han et al., 2010). Auto-calibration was run after every 8 samples. For the analysis, methane $\left(\mathrm{CH}_{4}\right)$ is used as the calibration gas. The repeatability error of OC and EC while analyzing the fPM was found to be in the range of $8-12 \%$, which is within the acceptable limit (Han et al., 2007). The quality control and quality assurance (QC \& QA) procedure has been followed as described previously in Cao et al. (2003).

About one-fourth of each filter $\left(3.1 \mathrm{~cm}^{2}\right)$ was used to analyze WSOC. For the analysis, each filter sample was sonicated and extracted thrice with $25 \mathrm{~mL}(=10+10+5 \mathrm{~mL})$ of Milli-Q water in a sterilized glass centrifuge tube. Sonication was done by placing sample tubes in an ultrasonic bath every time at 1 hertz for $30 \mathrm{~min}$ (each cycle) for extracting water-soluble fractions completely. Finally, all sample extracts of a particular sample were pooled and then filtered through a $0.2 \mu \mathrm{m}$ pore-size nylon syringe filter and subsequently analyzed on a total organic carbon (TOC) analyzer (Model TOC-LCPH E200 ROHS; Shimadzu). Potassium hydrogen phthalate (KHP) and sodium carbonate solutions were used to calibrate the instrument. Each sample was injected thrice and analyzed on TOC analyzer to achieve a coefficient of variation (CV) $<3 \%$. A small amount of the extracted sample was also used to analyze $\mathrm{K}^{+}$ions using ion chromatography (IC). The detailed principle and working of IC have been already discussed in previous studies (Tiwari and Kulshrestha, 2019; Mishra and Kulshrestha, 2020). Several field blanks (10\% of collected samples of each season) and lab blanks were also analyzed along with the batch of samples for QC \& QA.

\subsection{Secondary Organic Carbon (SOC) Estimation}

Secondary OC was estimated using the EC-tracer method (Turpin and Huntzicker, 1995; Cabada et al., 2004; Srivastava et al., 2018). This method assumes that the minimum OC/EC ratio involves OC contribution only from the primary emission source (Castro et al., 1999; Pavuluri et al., 2011). Accordingly, the minimum OC/EC ratio can be used for the estimation of primary OC (POC) and SOC. In this study, SOC was calculated for each season separately using the following equations:

$$
P O C=E C \times\left(\frac{O C}{E C}\right)_{\min }
$$


where $(\mathrm{OC} / \mathrm{EC})_{\min }$ represents the minimum value of $\mathrm{OC} / \mathrm{EC}$ ratio for each season. This value is 1.0 in winter, 0.9 in summer, 0.6 in monsoon and 1.1 in post-monsoon season.

\section{RESULTS AND DISCUSSION}

\subsection{Temporal Variability of fPM Mass Concentration}

Temporal variability of fPM mass concentration is shown in Fig. 3(a). The concentrations of fPM varied from 22-367 $\mu \mathrm{g} \mathrm{m}^{-3}$ during the entire study, with an annual mean of $149 \pm 87 \mu \mathrm{g} \mathrm{m}^{-3}$ at the site (Prayagraj, central IGP). The annual average fPM concentration was observed to be 3.7 times higher as compared to the National Ambient Air Quality Standard values (NAAQS; annual average $\mathrm{PM}_{2.5}: 40 \mu \mathrm{g} \mathrm{m}^{-3}$ ). It can be noticed that $\mathrm{PPM}$ concentrations were higher during winter and post-monsoon, followed by that in summer, and lowest in the monsoon season (Fig. 3(a)). The data set revealed that monthly averaged fPM concentration was maximum for November $\left(317 \mu \mathrm{g} \mathrm{m}^{-3}\right)$ whereas minimum for August $\left(47 \mu \mathrm{g} \mathrm{m}^{-3}\right)$. Our observation on higher concentrations of atmospheric particulates in the month of November is in good agreement with

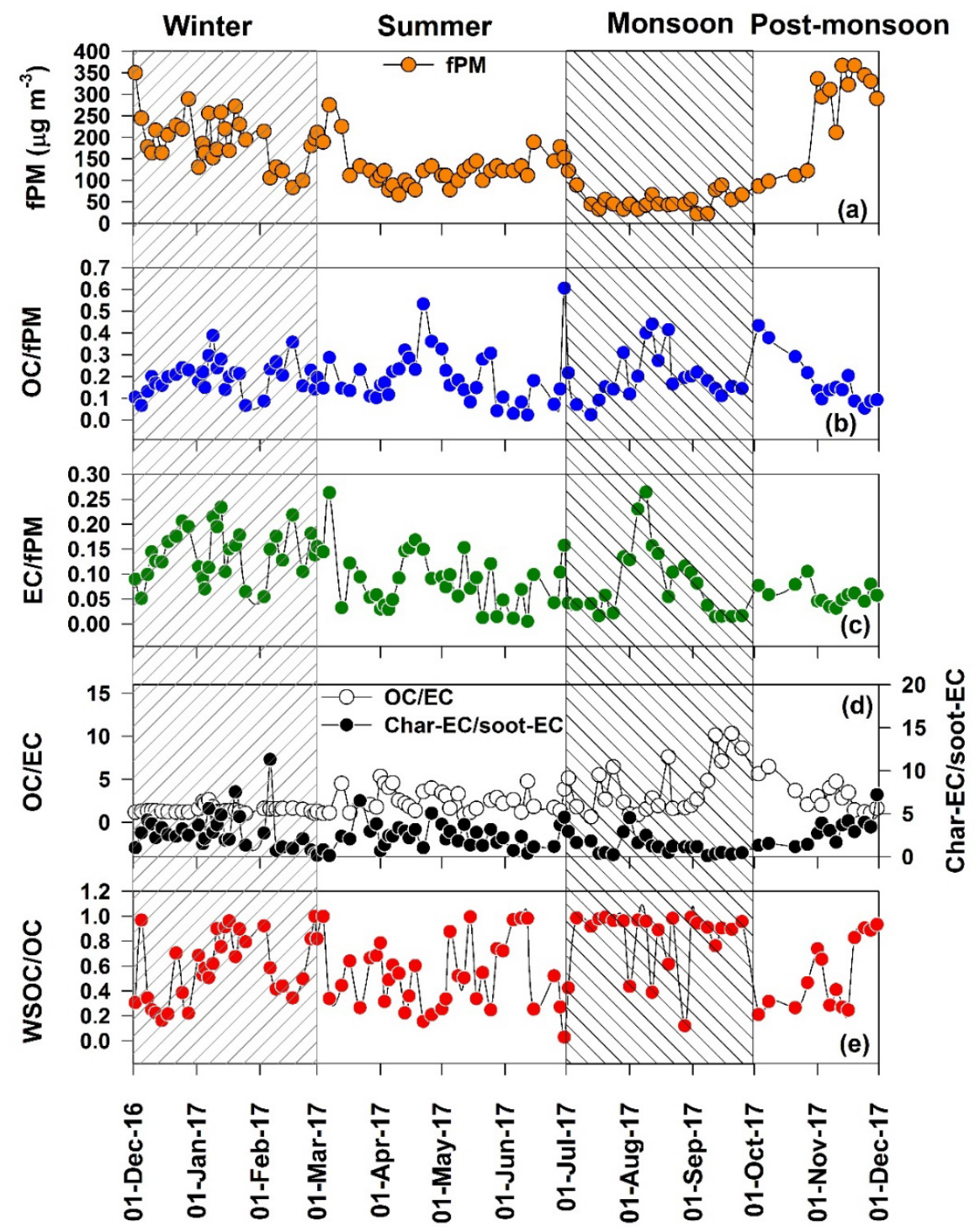

Fig. 3. Temporal variation of (a) fPM along with $\mathrm{RH}$ and temperature, (b) OC/fPM, (c) EC/fPM, (d) OC/EC and char-EC/soot-EC ratio, and (e) WSOC/OC ratio. 
the previous studies (Ram and Sarin, 2010; Ram et al., 2012; Pachauri et al., 2013; Singh et al., 2017; Rajput et al., 2018). Those studies have addressed the predominant impact through longrange transport of large-scale agricultural rice straw (hundreds of millions of tons) burning emissions occurring in the northwestern part of the IGP region (Sawlani et al., 2018). Frequent precipitation during the monsoon period from July to September is attributable to wet scavenging of ambient aerosols (Singh et al., 2017). During the peak winter months of December and January, the fPM averaged at 226 and $200 \mu \mathrm{g} \mathrm{m}^{-3}$, respectively. Moderate levels of fPM concentrations were observed during the summer months from March to June, with the lowest mean value in April $\left(99 \mu \mathrm{g} \mathrm{m}^{-3}\right)$. These observed values are nearly comparable to previous studies conducted at different sites of IGP (Kulshrestha et al., 1998; Ram and Sarin, 2010; Satasangi et al., 2012; Singh et al., 2017). The variability in the abundance pattern of ambient aerosols was found to be highly dependent on emission sources, seasonal meteorology, and atmospheric chemistry, which has been discussed in the following sections.

\subsection{Temporal Variability of Carbonaceous Aerosols}

The annual mean concentration of OC, EC and WSOC in FPM was observed to be $27.3 \pm 18.7$, $15.1 \pm 13.6$ and $13.9 \pm 10.5 \mu \mathrm{g} \mathrm{m}^{-3}$, respectively. A landscaping exercise was done for comparison in the spatial distribution of mass concentrations of OC, EC and WSOC from this study and studies reported earlier from different parts of India (Table 3). Temporal variabilities in the carbonaceous aerosol species, viz., OC/fPM, EC/fPM, OC/EC, char-EC/soot-EC and WSOC/OC ratio are shown in Figs. 3(b, c, d, e). Overall, OC/fPM varied from 0.02-0.61 (annual avg. \pm SD: $0.18 \pm 0.11$ ). Likewise, EC/fPM also exhibited a significant variability, ranging from $0.01-0.26(0.10 \pm 0.06)$. In other words, the OC and EC annually averaged mass fraction (\%) in FPM were $18 \%$ and $10 \%$, respectively (Figs. 3(b, c]). On average, the total carbonaceous aerosol (TCA $=O C \times 1.6+E C)$ at the present site was found to contribute about $39.4 \%$ of the fPM (annual mean: $149 \mu \mathrm{g} \mathrm{m}^{-3} ;$ Fig. 3(a)). The characteristic ratios of OC/EC and char-EC/soot-EC varied from 0.6-22.2 (2.8 \pm 2.8$)$ and 0.1-7.5 $(0.7 \pm 1.6)$, respectively, during the entire study period. The WSOC/OC ranged from $0.03-1.00$ $(0.61 \pm 0.29)$. Furthermore, to understand better the seasonal abundance of carbonaceous aerosols and their characteristic ratios, it is necessary to look at the impact of long-range transport of aerosols through air-mass analyses during different seasons.

\subsection{Concentration-weighted Trajectories and Cluster Analysis}

In the present study, air-mass backward trajectories (AMBTs) were simulated utilizing the National Oceanic and Atmospheric Administration (NOAA) Hybrid Single-Particle Lagrangian Integrated Trajectory (HYSPLIT) model with an input of Global Data Assimilation System (GDAS) meteorological data at an atmospheric height of $500 \mathrm{~m}$ above mean sea level (Draxler and Rolph, 2003). Due to the longer residence time of fine particulates, 7-day AMBTs were retrieved for each sampling date, the exception being in the winter season wherein 5-day AMBTs were taken into account owing to poor ventilation coefficient during the season. Furthermore, cluster analysis of the fPM data set has been performed for each of the four seasons (Figs. 4(a, b, c, d)). Briefly, the seasonally segregated trajectories were clustered with measured fPM mass concentration based on a pre-existing algorithm of the nearest angle-distance function (Sirois and Bottenheim, 1995). Moreover, we have also carried out the CWT analysis, which is also a receptor model used widely to understand the spatial distribution of potential source regions of air pollutants (Bansal et al., 2019; Rai et al., 2020). In CWT analysis, based on the stretch of AMBTs, the geographic region is firstly sub-divided into a set of grid cells (grid resolution: $0.5^{\circ} \times 0.5^{\circ}$ ). Subsequently, the CWT method determines the pollutant's concentration values in each grid cell based on integrated information and calculation of the average concentration of pollutant and air-mass residence time of AMBTs in the cell (Ghosh et al., 2015; Bansal et al., 2019). The outputs of CWT and cluster analysis for fPM during each season are shown in Figs. $4(a, b, c, d)$.

In the present study, trajectories were identified into two major clusters in each season except in the summer, wherein clustering the AMBTs into three groups explained the dominant pathways of aerosols arriving at the study site (Figs. $4(a, b, c, d)$ ). The trajectory clusters show that the mean pathways have a distinctly different seasonal pattern. For example, during wintertime, fPM showed association with two major clustered trajectories, originating from the northwestern part of India 
and contributed equally (50\%). Cluster \#1 represents the influence of long-range transport from northwest regions extending from Afghanistan and Pakistan (Fig. 4(a)). However, Cluster \#2 is representative of regional transport from upwind IGP (Fig. 4(a)). Summer months have witnessed the influence of air masses associated with three major clusters. Cluster \#1 comprised $36 \%$ of AMBTs from the western side of the study site and originated over Gulf countries and traversed through the Arabian Sea (Fig. 4(b)). Both Clusters \#2 and \#3 comprised equally (32\% of AMBTs) and followed a tract of southeastern (the Bay of Bengal and eastern states) and northwestern upwind region, respectively (Fig. 4(b)). The monsoon period has experienced by and large the influence of southwesterly air masses that originated over the northern Indian Ocean (Fig. 4(c)). Nearly $54 \%$ of air masses traverse through the Arabian Sea, whereas the remaining $46 \%$ of the air masses have a signature from the marine atmospheric boundary layer (MABL) over the Bay of Bengal (Fig. 4(c)). The lowest concentrations have been observed during the monsoon period attributable to deeper boundary layer height, high wind speed and reduced anthropogenic activities (particularly BB). Thus, the IGP experiences influence of air masses of mixed origins (continental/marine) during the summer and monsoon seasons. In the post-monsoon season, the highest mass concentration of fPM was found to be associated with Cluster \#1, indicating that most of the fine aerosols were transported from northwest direction (53\%) that includes states of Punjab, Haryana, Delhi and other upwind IGP regions and the northern part of Pakistan, while $47 \%$ of fPM was transported with easterly wind system as predicted by Cluster \#2 (Fig. 4(d)).

(a). CWT \& Cluster Analysis of winter season

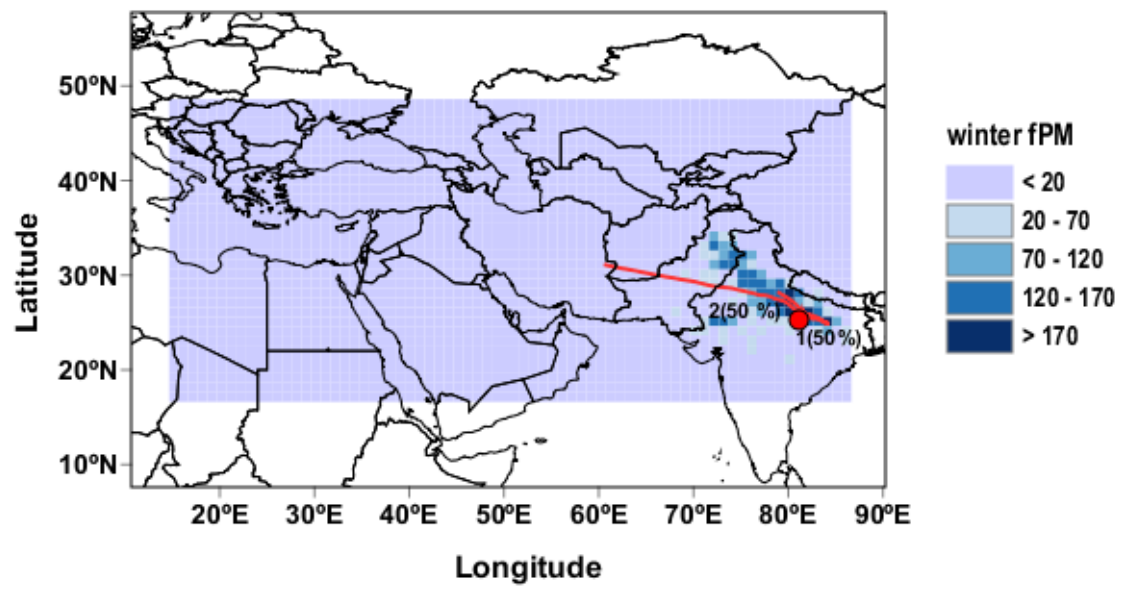

(b). CWT \& Cluster Analysis of summer season

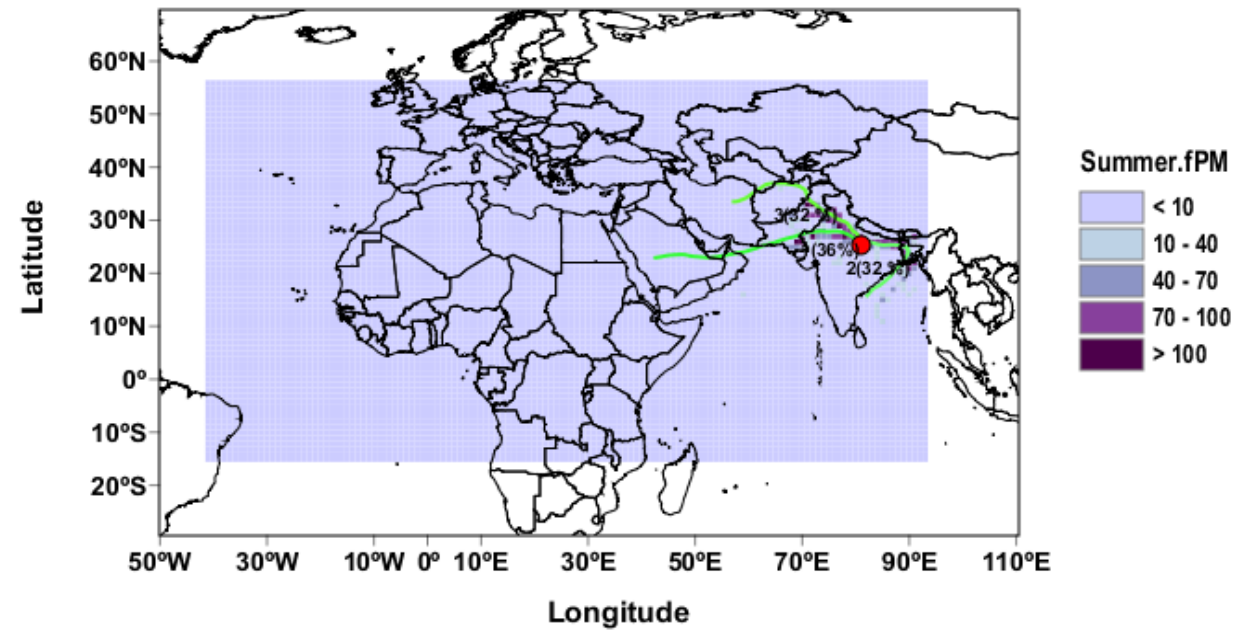

Fig. 4. CWT and cluster trajectory analysis at the sampling site during (a) winter, (b) summer, (c) monsoon and (d) post-monsoon season (figures are software-based and do not represent political map). 
(c). CWT \& Cluster Analysis of monsoon season

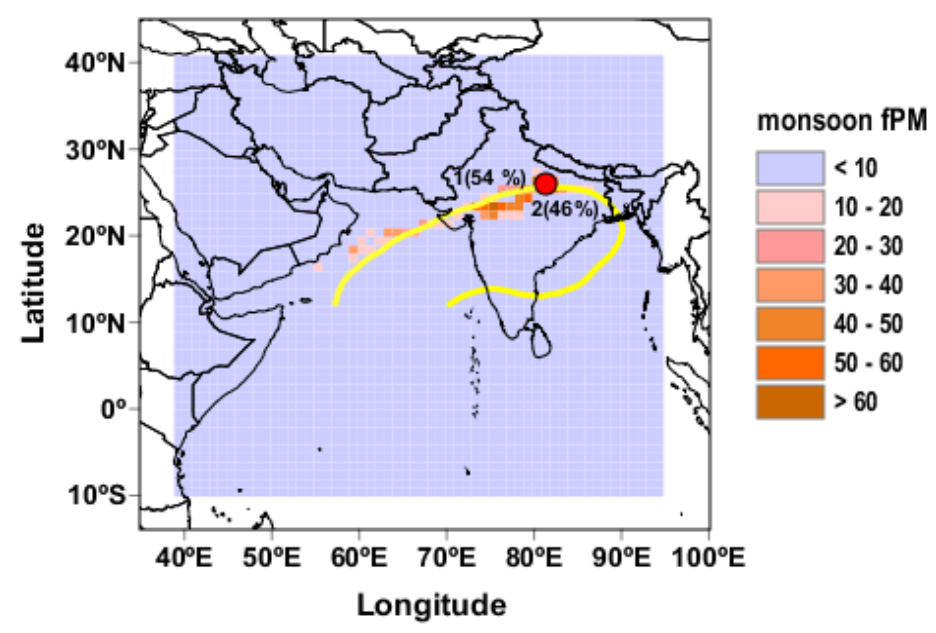

(d). CWT \& Cluster Analysis of Post-monsoon season

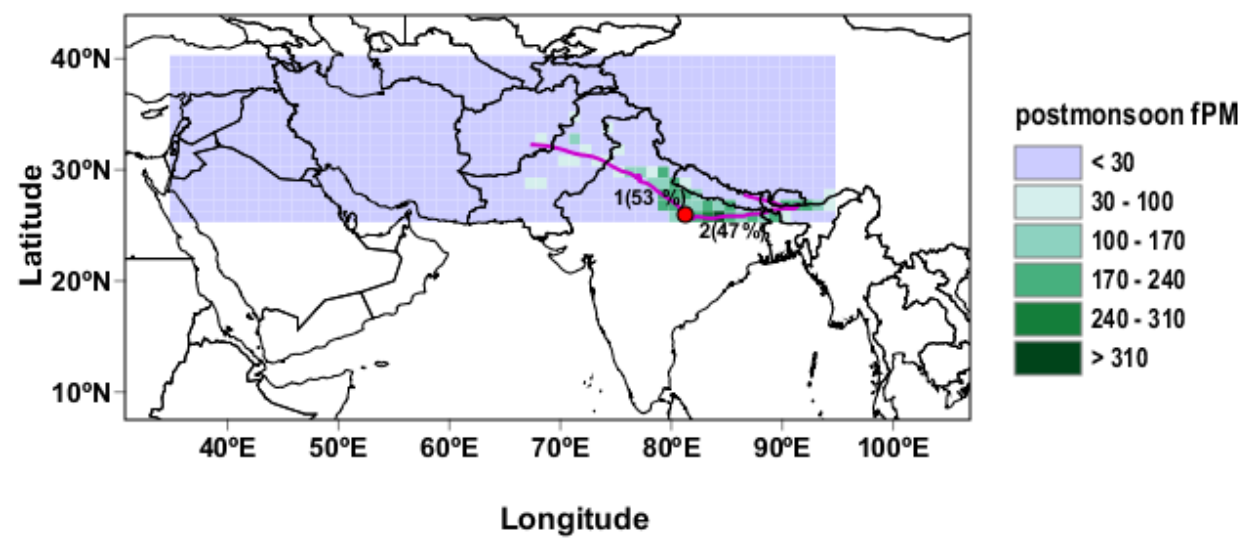

Fig. 4. (continued).

The higher concentrations of fPM in this study during post-monsoon and winter seasons and the prevailing northwesterly wind system suggest that local sources in conjunction with long-range transport are responsible for degrading air quality over the study region.

\subsection{Seasonal Variability of Carbonaceous Aerosols}

Seasonally averaged values of fPM, OC/fPM, EC/fPM, OC/EC, WSOC/OC, and char-EC/soot-EC ratio are represented in Figs. $5(a-f)$ and Table 1 . The seasonally averaged fPM concentration followed the trend: post-monsoon $\left(257 \pm 107 \mu \mathrm{g} \mathrm{m}^{-3}\right)>$ winter $\left(193 \pm 60 \mu \mathrm{g} \mathrm{m}^{-3}\right)>\operatorname{summer}(130$ $\left.\pm 44 \mu \mathrm{g} \mathrm{m}^{-3}\right)>$ monsoon $\left(53 \pm 24 \mu \mathrm{g} \mathrm{m}^{-3}\right.$ ) (Fig. 5(a)). The OC/fPM ( $\approx 0.20$; Fig. 5(b)) exhibited insignificant seasonal variability in this study (Fig. 5(b)). The EC/fPM exhibited a distinctly different seasonal variability pattern with highest concentration in winter and lowest during post-monsoon: winter $(0.14 \pm 0.05)>\operatorname{summer}(0.09 \pm 0.06)>$ monsoon $(0.08 \pm 0.07)>$ post-monsoon $(0.06 \pm$ 0.02 ) (Fig. 5(c)). The characteristic ratio of OC/EC showed the following pattern: monsoon ( $4.0 \pm$ $3.1)>\operatorname{summer}(3.1 \pm 3.5) \approx$ post-monsoon $(3.1 \pm 1.7)>$ winter $(1.4 \pm 0.4)$ (Fig. 5(d)). Observed values of OC, EC and OC/EC have been compared with previous studies conducted at various sites of India (Table 2) and were found to be in close range of the sites located in IGP. Furthermore, the seasonally averaged WSOC/OC ratio varied in the following manner: monsoon $(0.82 \pm 0.25)$ $>$ winter $(0.59 \pm 0.26)>$ post-monsoon $(0.53 \pm 0.28) \approx \operatorname{summer}(0.52 \pm 0.28)$ (Fig. $5(\mathrm{e}))$. Moreover, the characteristic ratio of char-EC/soot-EC showed the following pattern: winter $(3.1 \pm 2.2)>$ post-monsoon $(3.0 \pm 1.6) \approx \operatorname{summer}(2.3 \pm 1.4)>$ monsoon $(1.3 \pm 1.1)$ (Fig. 5(f)). The data set of each season were subjected to statistical one-way ANOVA in order to assess the significant difference in the seasonally averaged mass concentration/ratio of analyzed parameters (Table S1). 
Table 1. Seasonal record in mass concentration statistics of different carbonaceous fractions in ambient aerosols from Prayagraj (this study).

\begin{tabular}{|c|c|c|c|c|c|c|c|c|}
\hline \multicolumn{9}{|c|}{ Concentrations $\left(\mu \mathrm{g} \mathrm{m}^{-3}\right)$} \\
\hline \multirow[t]{2}{*}{ Parameters } & \multicolumn{2}{|c|}{ Winter $(n=30)$} & \multicolumn{2}{|c|}{ Summer $(n=36)$} & \multicolumn{2}{|c|}{ Monsoon $(n=22)$} & \multicolumn{2}{|c|}{ Post-monsoon $(n=14)$} \\
\hline & Range & Avg. \pm SD & Range & Avg. \pm SD & Range & Avg. \pm SD & Range & Avg. \pm SD \\
\hline fPM & $83-350$ & $193 \pm 60$ & $67-275$ & $130 \pm 44$ & $22-122$ & $53 \pm 24$ & $87-367$ & $257 \pm 107$ \\
\hline OC & $13.0-75.7$ & $37.4 \pm 16.7$ & $3-93$ & $25.8 \pm 19.8$ & $1.1-29.4$ & $10.3 \pm 7.0$ & $18.7-65.7$ & $36.2 \pm 12.0$ \\
\hline EC & $10.5-60.4$ & $26.9 \pm 13.2$ & $1-72$ & $12.4 \pm 12.7$ & $0.6-11.2$ & $3.9 \pm 3.1$ & $5.7-26.3$ & $14.2 \pm 6.2$ \\
\hline OC/fPM & $0.07-0.39$ & $0.20 \pm 0.08$ & $0.02-0.58$ & $0.20 \pm 0.13$ & $0.03-0.44$ & $0.20 \pm 0.11$ & $0.05-0.43$ & $0.18 \pm 0.12$ \\
\hline EC/fPM & $0.05-0.23$ & $0.14 \pm 0.05$ & $0.01-0.26$ & $0.09 \pm 0.06$ & $0.01-0.26$ & $0.08 \pm 0.07$ & $0.03-0.11$ & $0.06 \pm 0.02$ \\
\hline OC/EC & $1.0-2.6$ & $1.4 \pm 0.4$ & $0.9-22.2$ & $3.1 \pm 3.5$ & $0.6-10.3$ & $4.0 \pm 3.1$ & $1.1-6.5$ & $3.1 \pm 1.7$ \\
\hline Char-EC/soot-EC & $0.3-11.3$ & $3.1 \pm 2.2$ & $0.1-6.5$ & $2.3 \pm 1.4$ & $0.1-4.5$ & $1.3 \pm 1.1$ & $1.2-7.2$ & $3.0 \pm 1.6$ \\
\hline WSOC & $4.3-54.4$ & $21.5 \pm 13.3$ & $2.6-33.9$ & $10.4 \pm 6.6$ & $1.0-11.5$ & $7.0 \pm 3.5$ & $8.0-34.0$ & $17.4 \pm 7.7$ \\
\hline WSOC/OC & $0.16-1.00$ & $0.59 \pm 0.26$ & $0.02-1.00$ & $0.52 \pm 0.28$ & $0.12-0.99$ & $0.82 \pm 0.25$ & $0.21-0.93$ & $0.53 \pm 0.28$ \\
\hline POC & $10.5-60.4$ & $26.9 \pm 13.2$ & $0.5-65.2$ & $11.2 \pm 11.5$ & $0.3-6.9$ & $2.4 \pm 1.9$ & $6.3-29.0$ & $15.6 \pm 6.8$ \\
\hline SOC & $0.0-46.7$ & $10.5 \pm 8.8$ & $0.0-71.2$ & $14.6 \pm 14.4$ & $0.0-23.3$ & $7.9 \pm 6.1$ & $0.0-44.9$ & $20.5 \pm 13.4$ \\
\hline
\end{tabular}

Table 2. Reported concentrations of OC, EC and WSOC $\left(\mu \mathrm{g} \mathrm{m}^{-3}\right)$ in atmospheric aerosols from various geographical locations in India and few locations in China.

\begin{tabular}{|c|c|c|c|c|c|c|c|c|}
\hline Region & Site & Duration & Aerosols & OC & EC & OC/EC & WSOC & Reference \\
\hline Prayagraj & Urban & Annual & fPM & 27.3 & 15.1 & 2.8 & 13.9 & This study \\
\hline Delhi & Urban & Annual & $\mathrm{PM}_{2.5}$ & 15.7 & 7.3 & 2.2 & - & Jain et al. $(2021 b)^{\$}$ \\
\hline Delhi & Urban & Annual & $\mathrm{PM}_{10}$ & 26.6 & 9.3 & 2.8 & - & Jain et al. $(2021 b)^{\$}$ \\
\hline Delhi & Urban & Annual & $\mathrm{PM}_{2.5}$ & 23.9 & 4.2 & 5.9 & 15.2 & Bhowmik et al. (2021) \\
\hline Hisar & Urban & Annual & $\mathrm{PM}_{2.5}$ & 18.9 & 2.5 & 7.0 & 12.5 & Bhowmik et al. (2021) \\
\hline Kanpur & Urban & Annual & $\mathrm{PM}_{2.5}$ & 16.0 & 2.8 & 6.2 & 15.0 & Bhowmik et al. (2021) \\
\hline Bhimtal & Sensitive & Annual & TSP & 15.7 & 4.5 & 3.5 & - & Kumar et al. (2021a) \\
\hline Lumbini & Rural & Annual & TSP & 32.1 & 6.4 & 4.8 & 15.5 & Chen et al. $(2020)^{\$}$ \\
\hline Darjeeling & Sensitive & Annual & $\mathrm{PM}_{10}$ & 5.1 & 2.4 & 2.7 & 3.7 & Rai et al. (2020)\$ \\
\hline Kolkata & Urban & Annual & fPM & 24.1 & 7.2 & 3.5 & - & Priyadharshini et al. (2019) \\
\hline Trivandrum & Coastal & Annual & $\mathrm{PM}_{10}$ & 8.6 & 2.0 & 6.3 & 3.2 & Aswini et al. (2019) \\
\hline Giridh & Suburban & Winter & $\mathrm{PM}_{10}$ & 37.2 & 15.2 & 2.4 & - & Sharma et al. $(2018)^{\$}$ \\
\hline Raipur & Urban & Annual & $\mathrm{PM}_{2.5}$ & 36.4 & 10.4 & 3.5 & - & Sahu et al. $(2018)^{\$}$ \\
\hline Trivandrum & Coastal & Annual & TSP & 17.0 & 3.3 & 5.2 & 6.1 & Hegde and Kawamura (2017) \\
\hline Delhi & Urban & Winter & $\mathrm{PM}_{2.5}$ & 33.5 & 6.9 & 5.1 & - & Dumka et al. (2017) \\
\hline Delhi & Urban & Annual & $\mathrm{PM}_{2.5}$ & 25.6 & 13.7 & 2.2 & - & Singh et al. $(2016)^{\$}$ \\
\hline Gurugram & Rural & Annual & $\mathrm{PM}_{2.5}$ & 29.2 & 12.6 & 2.6 & - & Singh et al. $(2016)^{\$}$ \\
\hline Delhi & Urban & Annual & $\mathrm{PM}_{10}$ & 26.7 & 6.1 & 4.4 & - & Sharma et al. $(2014)^{\$}$ \\
\hline Barapani & Sensitive & Winter & $\mathrm{PM}_{2.5}$ & 39.0 & 5.9 & 6.6 & 25.5 & Rajput et al. (2013) \\
\hline Kanpur & Urban & Winter & $\mathrm{PM}_{2.5}$ & 41.2 & 5.5 & 7.8 & 30.1 & Ram et al. (2012) \\
\hline Chennai & Urban & Winter & $\mathrm{PM}_{10}$ & 9.1 & 6.5 & 1.5 & - & Pavuluri et al. $(2011)^{\$}$ \\
\hline Prayagraj & Urban & Winter & TSP & 49.0 & 6.2 & 8.1 & 17.7 & Ram and Sarin (2010) \\
\hline Hisar & Urban & Winter & TSP & 30.9 & 3.8 & 8.5 & 10.7 & Ram and Sarin (2010) \\
\hline Kanpur & Urban & Winter & TSP & 25.0 & 4.8 & 6.2 & 8.8 & Ram and Sarin (2010) \\
\hline
\end{tabular}

$\$$ Measured utilizing the IMPROVE-A protocol, otherwise by the NIOSH protocol.

The ANOVA has been carried out using the SPSS (version 20) software. The results were considered significant for a $p$-value $<0.05$. All the parameters, including $\mathrm{PPM}, \mathrm{EC} / \mathrm{fPM}, \mathrm{OC} / \mathrm{EC}, \mathrm{WSOC} / \mathrm{OC}$, and char-EC/soot-EC ratio were found statistically different, with the exception being the OC/fPM ratio. A significant statistical seasonal difference in various carbonaceous aerosol components is attributable to the varying contribution from emission sources, meteorological conditions (like rainfall vs. drier period, low wind speed vs. high wind speed, shallower vs. deeper boundary layer height), and atmospheric chemistry (e.g., secondary aerosol formation). 

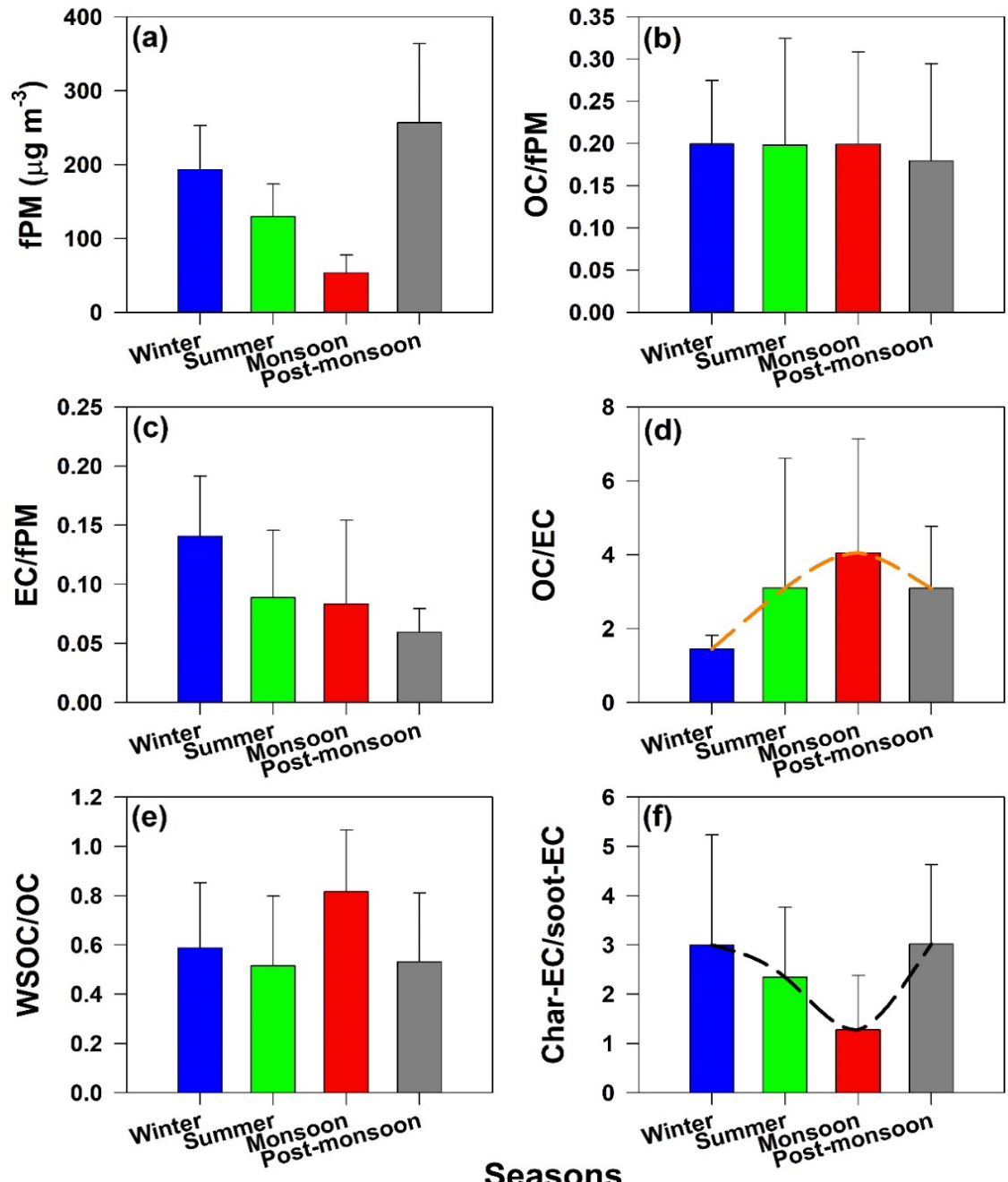

Fig. 5. Seasonal variability (avg. $\pm 1 \sigma$ ) of (a) fPM, (b) OC/fPM, (c) EC/fPM, (d) OC/EC, (e) WSOC/OC and (f) Char-EC/soot-EC.

\subsection{Source Identification}

Previous studies have reported distinct ratios of OC/EC and char-EC/soot-EC for different source identification, as represented in Table 3. To identify probable sources of carbonaceous aerosols at the study site in each season, we have constructed a cross plot employing the mean value of existing data sets of OC/EC and char-EC/soot-EC ratios for various sources, viz., biomass burning, biofuel burning, coal combustion, and vehicular emissions (Fig. 6). The mean value of $\mathrm{OC} / \mathrm{EC}$ and char-EC/soot-EC (taken from existing literature as shown in Table 3) was reported to be $6.0 \pm 4.6$ and $4.8 \pm 2.2$ for biomass burning, $3.3 \pm 0.9$ and $5.4 \pm 2.8$ for biofuel burning, $4.3 \pm$ 1.9 and $1.3 \pm 0.8$ for coal combustion and $1.3 \pm 0.5$ and $0.6 \pm 0.4$ for vehicular emissions, respectively. Since both of these ratios have been established to trace the sources of carbonaceous aerosols (Table 3), we have coupled them to utilize as reference values to better understand the dominant sources (Fig. 6) (Han et al., 2010; Ram et al., 2012; Pani et al., 2019; Kumar et al., 2021b). Apart from char-EC, the $\mathrm{K}^{+}$ions are also predominantly used to trace out biomass burning emissions (Cheng et al., 2013). Thus, a regression analysis of OC/EC and char/soot-EC with $\mathrm{K}^{+}$was conducted for each season (Fig. S1). The ratio analysis of the winter season has shown that there is an influence of both biomass and fossil-fuel emissions (Fig. 6(a)). However, a strong correlation of $\mathrm{K}^{+}$with char/soot-EC $(r=0.85)$ as compared to OC/EC $(r=0.22)$ with higher mean $\mathrm{K}^{+}$value $\left(7.1 \mu \mathrm{g} \mathrm{m}^{-3}\right.$ ) clearly indicated the dominance of biomass-burning sources in winter months (Fig. S1(a)). Biomass burning was also observed as a major source in post-monsoon season owing to the strong correlation of char/soot-EC ratios with $\mathrm{K}^{+}(r=0.92)$ with higher average levels of $\mathrm{K}^{+}$ 
Table 3. Literature-based emission characteristics of various sources based on OC/EC and char-EC/soot-EC ratios.

\begin{tabular}{lllll}
\hline Study area & OC/EC & Char-EC/soot-EC & Sources & Reference \\
\hline Xi'an, China & 4.6 & 4.4 & Biomass burning & Han et al. (2010) \\
Haikou, China & 2.2 & 7.1 & Biomass burning & Liu et al. (2018) \\
Shanghai, China & 11.3 & 2.8 & Biomass burning & Wang et al. (2019) \\
Xi'an, China & 2.6 & 7.3 & Biofuel burning & Han et al. (2016) \\
Raipur, India & 3.9 & 3.4 & Biofuel burning & Sahu et al. (2018) \\
Texas, U.S. & 1.9 & 1.1 & Vehicular emission & Chow et al. (2004) \\
Texas, U.S. & 1.1 & 0.4 & Vehicular emission & Chow et al. (2004) \\
Hong Kong & 1 & 0.3 & Diesel exhausts & Cao et al. (2006) \\
& & 0.7 & Gasoline emissions & Chow et al. (2004) \\
Texas, U.S. & 2.6 & 0.4 & Coal combustion & Han et al. (2008) \\
Daihai area, China & 6.4 & 1.8 & Coal combustion & Cao et al. (2013) \\
Shanghai, China & 3.8 & 1.7 & Coal combustion & \\
\hline
\end{tabular}

(a)

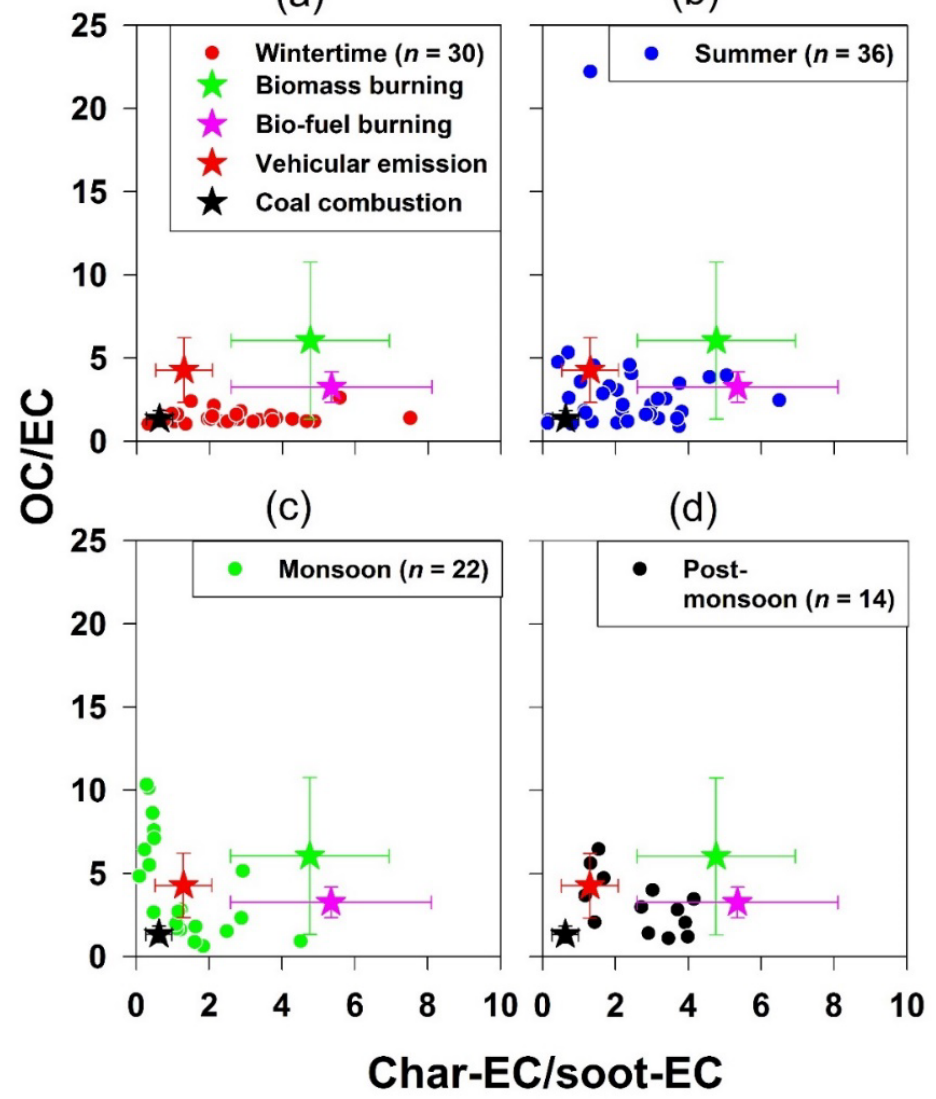

Fig. 6. Cross plots of OC/EC and char-EC/soot-EC for identification of seasonal emission sources during (a) wintertime, (b) summer, (c) monsoon, and (d) post-monsoon. The data set from this study are shown by circles whereas the literature-based source values of OC/EC and char$\mathrm{EC} /$ soot-EC are shown by star symbols (for source values, reference is made to Table 4).

$\left(5.3 \mu \mathrm{g} \mathrm{m}^{-3}\right)$ (Fig. S1(d)). However, no correlation of $\mathrm{K}^{+}$with OC/EC $(r=-60)$ can be attributed to the greater presence of SOA in the post-monsoon season. This further relates to the observations reported by previous studies on the long-range transport of paddy-residue burning emissions from upwind IGP (Rajput et al., 2016). During summer and monsoon season, it appeared to have a predominant impact of fossil-fuel (vehicular emission and coal combustion) sources with lower mean $\mathrm{K}^{+}$values (2.2 and $1.5 \mu \mathrm{g} \mathrm{m}^{-3}$, respectively) (Figs. 6(c) and (6(d)). Furthermore, $\mathrm{K}^{+}$in fPM remained strongly correlated with char/soot EC as compared to OC/EC in all the seasons, which 


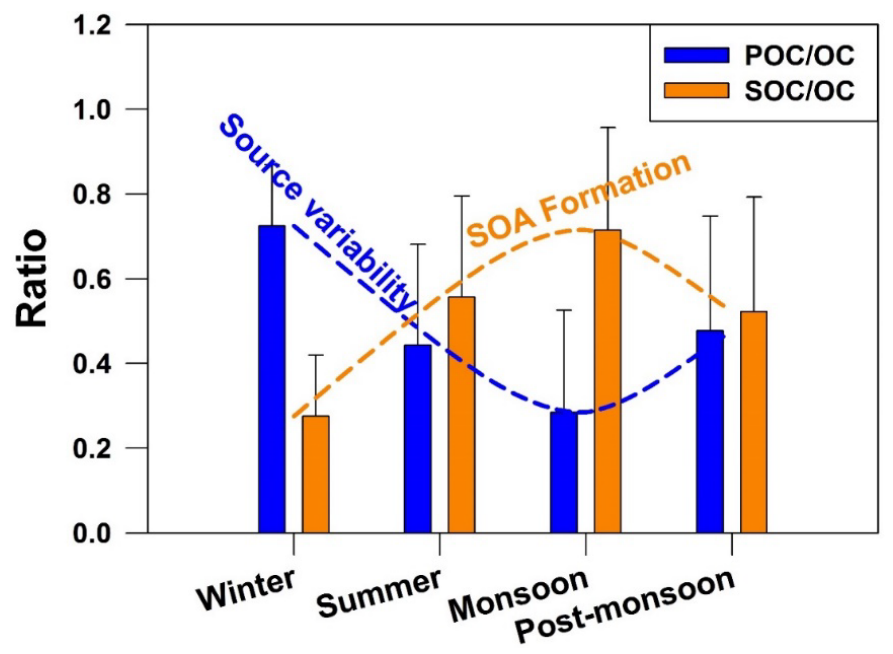

Fig. 7. Seasonal trend in $\mathrm{SOC} / \mathrm{OC}$ and $\mathrm{POC} / \mathrm{OC}$ ratios depicting variability of $\mathrm{POA}$ and SOA abundance in IGP.

clearly established that the char/soot-EC ratio is a better indicator for source identification as compared to OC/EC at the study site (Fig. S1) in ambient air owing to the influence of differential scavenging pattern (of OC and EC) and SOA formation (Boreddy et al., 2018). Pani et al. (2019) have also found char/soot-EC ratio as a good indicator of BB and FFC sources over urban sites. Furthermore, the studies using receptor modeling approaches such as positive matrix factorization (PMF) and chemical mass balance (CMB) with the incorporation of molecular markers would be more helpful in accurately quantifying the source contribution over the Prayagraj site.

\subsection{Source Variability and Secondary Organic Aerosol Formation}

SOA can be formed primarily by photochemistry or aqueous-phase reactions of volatile organic compounds (VOCs) (Seinfeld and Pandis, 2016). The SOC/OC ratio was found to be highest during monsoon $(0.7 \pm 0.2)$, followed by summer $(0.6 \pm 0.3)$, post-monsoon $(0.5 \pm 0.3)$ and lowest in winter $(0.3 \pm 0.1)$. The seasonal variability trend of the POC/OC ratio is quite opposite to that of SOC/OC ratio (Fig. 7). Both $\mathrm{POC}$ and SOC fractions were found to exhibit significantly high ( $p<$ 0.05 ) seasonal differences. The mass fraction of SOC is always larger than the contribution by POC, the exception being the observation during wintertime when POC/OC ratio is higher than the SOC/OC ratio. Summing up, a distinctly different and opposite seasonal trend for primary and secondary fractions of OA over central IGP has been found in this study (Fig. 7).

\section{CONCLUSION}

In this study, we assessed the temporal variability of the atmospheric fPM (dia. $<2.5 \mu \mathrm{m})$ as well as the mass concentrations and key ratios (OC/fPM, EC/fPM, OC/EC, char-EC/soot-EC, and WSOC/OC) of the associated carbonaceous aerosol species above Prayagraj (on the central IGP) for a period of 1 year. The major findings are as follows.

1. We observed significant seasonality in the variability of $\mathrm{PPM}$, and the mass concentrations and ratios (excluding OC/fPM) of the carbonaceous aerosols, which constituted $\sim 40 \%$ of the annual fPM mass concentration at the sampling site.

2. Our trajectory cluster and CWT analyses revealed an association between higher concentrations of fPM and carbonaceous aerosols at the study site, which mainly occurred during the postmonsoon season and winter, and prevailing northwesterly air masses. However, anthropogenic emissions from local sources dominated the fPM and carbonaceous aerosols in summer and the monsoon season, during which we also observed the influence of air masses of mixed (continental/marine) origin.

3. Utilizing the char-EC/soot-EC ratio in conjunction with the $\mathrm{OC} / \mathrm{EC}$ ratio and $\mathrm{K}^{+}$mass concentration, we identified biomass burning as the primary source of carbonaceous aerosols 
during the post-monsoon season and winter but fossil-fuel combustion as the predominant contributor during summer and the monsoon season.

4. BB and FFC sources of the fPM-bound carbonaceous aerosols above the central IGP can be traced using the char-EC/soot-EC ratio.

\section{ACKNOWLEDGEMENTS}

We sincerely thank the financial support received from CSIR, DST-PURSE and CIF Facility in School of Environmental Sciences, Jawaharlal Nehru University, New Delhi, to conduct this research work.

\section{REFERENCES}

Aswini, A.R., Hegde, P., Nair, P.R., Aryasree, S. (2019). Seasonal changes in carbonaceous aerosols over a tropical coastal location in response to meteorological processes. Sci. Total Environ. 656, 1261-1279. https://doi.org/10.1016/j.scitotenv.2018.11.366

Bansal, O., Singh, A., Singh, D. (2019). Characteristics of Black Carbon aerosols over Patiala Northwestern part of the IGP: Source apportionment using cluster and CWT analysis. Atmos. Pollut. Res. 10, 244-256. https://doi.org/10.1016/j.apr.2018.08.001

Bhowmik, H.S., Naresh, S., Bhattu, D., Rastogi, N., Prévôt, A.S.H., Tripathi, S.N. (2021). Temporal and spatial variability of carbonaceous species (EC; OC; WSOC and SOA) in $\mathrm{PM}_{2.5}$ aerosol over five sites of Indo-Gangetic Plain. Atmos. Pollut. Res. 12, 375-390. https://doi.org/10.1016/j.ap r.2020.09.019

Boreddy, S.K.R., Mozammel Haque, M., Kawamura, K. (2018). Long-term (2001-2012) trends of carbonaceous aerosols from a remote island in the western North Pacific: An outflow region of Asian pollutants. Atmos. Chem. Phys. 18, 1291-1306. https://doi.org/10.5194/acp-18-12912018

Brooks, J., Allan, J.D., Williams, P.I., Liu, D., Fox, C., Haywood, J., Langridge, J.M., Highwood, E.J., Kompalli, S.K., O'Sullivan, D., Babu, S.S., Satheesh, S.K., Turner, A.G., Coe, H. (2019). Vertical and horizontal distribution of submicron aerosol chemical composition and physical characteristics across northern India during pre-monsoon and monsoon seasons. Atmos. Chem. Phys. 19, 5615-5634. https://doi.org/10.5194/acp-19-5615-2019

Cabada, J.C., Pandis, S.N., Subramanian, R., Robinson, A.L., Polidori, A., Turpin, B. (2004). Estimating the secondary organic aerosol contribution to $\mathrm{PM}_{2.5}$ using the EC tracer method special issue of aerosol science and technology on findings from the fine particulate matter supersites program. Aerosol Sci. Technol. 38, 140-155. https://doi.org/10.1080/02786820390 229084

Cao, J.J., Lee, S.C., Ho, K.F., Zhang, X.Y., Zou, S.C., Fung, K., Chow, J.C., Watson, J.G. (2003). Characteristics of carbonaceous aerosol in Pearl River Delta Region, China during 2001 winter period. Atmos. Environ. 37, 1451-1460. https://doi.org/10.1016/S1352-2310(02)01002-6

Castro, L.M., Pio, C.A., Harrison, R.M., Smith, D.J.T. (1999). Carbonaceous aerosol in urban and rural European atmospheres: Estimation of secondary organic carbon concentrations. Atmos. Environ. 33, 2771-2781. https://doi.org/10.1016/S1352-2310(98)00331-8

Chen, P., Kang, S., Tripathee, L., Panday, A.K., Rupakheti, M., Rupakheti, D., Zhang, Q., Guo, J., Li, C., Pu, T. (2020). Severe air pollution and characteristics of light-absorbing particles in a typical rural area of the Indo-Gangetic Plain. Environ. Sci. Pollut. Res. 27, 10617-10628. https://doi.org/10.1007/s11356-020-07618-6

Cheng, Y., Engling, G., He, K.B., Duan, F.K., Ma, Y.L., Du, Z.Y., Liu, J.M., Zheng, M., Weber, R.J. (2013). Biomass burning contribution to Beijing aerosol. Atmos. Chem. Phys. 13, 7765-7781. https://doi.org/10.5194/acp-13-7765-2013

Chow, J.C., Watson, J.G., Chen, L.W.A., Chang, M.C.O., Robinson, N.F., Trimble, D., Kohl, S. (2007) The IMPROVE_A temperature protocol for thermal/optical carbon analysis: Maintaining consistency with a long-term database. J. Air Waste Manage. Assoc. 57, 1014-1023. https://doi.org/10.3155/1047-3289.57.9.1014

Draxler, R., Rolph, G. (2003). HYSPLIT (HYbrid Single-Particle Lagrangian Integrated Trajectory) 
Model Access via NOAA ARL READY Website. NOAA Air Resources Laboratory.

Dumka, U.C., Tiwari, S., Kaskaoutis, D.G., Hopke, P.K., Singh, J., Srivastava, A.K., Bisht, D.S., Attri, S.D., Tyagi, S., Misra, A., Pasha, G.S.M. (2017). Assessment of $\mathrm{PM}_{2.5}$ chemical compositions in Delhi: primary vs secondary emissions and contribution to light extinction coefficient and visibility degradation. J. Atmos. Chem. 74, 423-450. https://doi.org/10.1007/s10874-0169350-8

Finlayson-Pitts, B.J., Pitts, J.N. (2000). CHAPTER 4 - Photochemistry of Important Atmospheric Species, in: Chemistry of the Upper and Lower Atmosphere, Academic Press, San Diego, pp. 86-129. https://doi.org/10.1016/B978-012257060-5/50006-X

Gelencsér, A. (2004). Carbonaceous Aerosol. Springer Netherlands, Dordrecht. https://doi.or g/10.1007/978-1-4020-2887-8

Ghosh, S., Biswas, J., Guttikunda, S., Roychowdhury, S., Nayak, M. (2015). An investigation of potential regional and local source regions affecting fine particulate matter concentrations in Delhi, India. J. Air Waste Manage. Assoc. 65, 218-231. https://doi.org/10.1080/10962247.201 4.982772

Granat, L., Norman, M., Leck, C., Kulshrestha, U.C., Rodhe, H. (2002). Wet scavenging of sulfur compounds and other constituents during the Indian Ocean Experiment (INDOEX). J. Geophys. Res. 107, 8025. https://doi.org/10.1029/2001JD000499

Han, Y., Cao, J., Chow, J.C., Watson, J.G., An, Z., Jin, Z., Fung, K., Liu, S. (2007). Evaluation of the thermal/optical reflectance method for discrimination between char- and soot-EC. Chemosphere 69, 569-574. https://doi.org/10.1016/j.chemosphere.2007.03.024

Han, Y.M., Lee, S.C., Cao, J.J., Ho, K.F., An, Z.S. (2009). Spatial distribution and seasonal variation of char-EC and soot-EC in the atmosphere over China. Atmos. Environ. 43, 6066-6073. https://doi.org/10.1016/j.atmosenv.2009.08.018

Han, Y.M., Cao, J.J., Lee, S.C., Ho, K.F., An, Z.S. (2010). Different characteristics of char and soot in the atmosphere and their ratio as an indicator for source identification in Xi'an, Chin. Atmos. Chem. Phys. 10, 595-607. https://doi.org/10.5194/acp-10-595-2010

Han, Y.M., Chen, L.W.A., Huang, R.J., Chow, J.C., Watson, J.G., Ni, H.Y., Liu, S.X., Fung, K.K., Shen, Z.X., Wei, C., Wang, Q.Y., Tian, J., Zhao, Z.Z., Prévôt, A.S.H., Cao, J.J. (2016). Carbonaceous aerosols in megacity Xi'an, China: Implications of thermal/optical protocols comparison. Atmos. Environ. 132, 58-68. https://doi.org/10.1016/j.atmosenv.2016.02.023

Hand, J.L., Schichtel, B.A., Pitchford, M., Malm, W.C., Frank, N.H. (2012). Seasonal composition of remote and urban fine particulate matter in the United States. J. Geophys. Res. 117, D05209. https://doi.org/10.1029/2011JD017122

Hegde, P., Kawamura, K. (2017). Chemical Constituents of Carbonaceous and Nitrogen Aerosols over Thumba Region, Trivandrum, India. Arch. Environ. Contam. Toxicol. 73, 456-473. https://doi.org/10.1007/s00244-017-0426-5

Jain, S., Sharma, S.K., Srivastava, M.K., Chatterjee, A., Vijayan, N., Tripathy, S.S., Kumari, K.M., Mandal, T.K., Sharma, C. (2021a). Chemical characterization, source apportionment and transport pathways of $\mathrm{PM}_{2.5}$ and $\mathrm{PM}_{10}$ over Indo Gangetic Plain of India. Urban Clim. 36, 100805. https://doi.org/10.1016/j.uclim.2021.100805

Jain, S., Sharma, S.K., Vijayan, N., Mandal, T.K. (2021b). Investigating the seasonal variability in source contribution to $\mathrm{PM}_{2.5}$ and $\mathrm{PM}_{10}$ using different receptor models during 2013-2016 in Delhi, India. Environ. Sci. Pollut. Res. 28, 4660-4675. https://doi.org/10.1007/s11356-02010645-y

Jimenez, J.L., Canagaratna, M.R., Donahue, N.M., Prevot, A.S.H., Zhang, Q., Kroll, J.H., DeCarlo, P.F., Allan, J.D., Coe, H., Ng, N.L., Aiken, A.C., Docherty, K.S., Ulbrich, I.M., Grieshop, A.P., Robinson, A.L., Duplissy, J., Smith, J.D., Wilson, K.R., Lanz, V.A., Hueglin, C., et al. (2009). Evolution of organic aerosols in the atmosphere. Science 326, 1525-1529. https://doi.org/10.1126/science. 1180353

Kumar, A., Singh, S., Kumar, N., Singh, N., Kumar, K., Chourasiya, S. (2021a). Assessment of carbonaceous fractions in ambient aerosols at high altitude and lowland urban locations of Kumaon Province, Indian Himalaya. SN Appl. Sci. 3, 83. https://doi.org/10.1007/s42452-02004010-4

Kumar, A., Singh, S., Kumar, N., Singh, N., Kumar, K., Mishra, A.K., Chourasiya, S., Kushwaha, H.S. (2021b). Seasonal abundance and source attribution of carbonaceous aerosols at different 
altitude of mountainous locations in Uttarakhand Himalaya. Aerosol Sci. Eng. 5, 233-246. https://doi.org/10.1007/s41810-021-00098-2

Leck, C., Persson, C. (1996). Seasonal and short-term variability in dimethyl sulfide, sulfur dioxide and biogenic sulfur and sea salt aerosol particles in the arctic marine boundary layer during summer and autumn. Tellus Ser. B 48, 272-299. https://doi.org/10.3402/tellusb.v48i2.15891

Mishra, M., Kulshrestha, U.C. (2020). Extreme air pollution events spiking ionic levels at urban and rural sites of Indo-Gangetic plain. Aerosol Air Qual. Res. 20, 1266-1281. https://doi.org/1 0.4209/aaqr.2019.12.0622

Pachauri, T., Satsangi, A., Singla, V., Lakhani, A., Kumari, K.M. (2013). Characteristics and sources of carbonaceous aerosols in $\mathrm{PM}_{2.5}$ during wintertime in Agra, India. Aerosol Air Qual. Res. 13, 977-991. https://doi.org/10.4209/aaqr.2012.10.0263

Pal, R., Chowdhury, S., Dey, S., Sharma, A.R. (2018). 8-year ambient PM2.5 exposure and night light trends in Indian cities: Vulnerability assessment. Aerosol Air Qual. Res. 18, 2332-2342. https://doi.org/10.4209/aaqr.2017.10.0425

Pani, S.K., Chantara, S., Khamkaew, C., Lee, C. Te, Lin, N.H. (2019). Biomass burning in the northern peninsular Southeast Asia: Aerosol chemical profile and potential exposure. Atmos. Res. 224, 180-195. https://doi.org/10.1016/j.atmosres.2019.03.031

Pavuluri, C.M., Kawamura, K., Aggarwal, S.G., Swaminathan, T. (2011). Characteristics, seasonality and sources of carbonaceous and ionic components in the tropical aerosols from Indian region. Atmos. Chem. Phys. 11, 8215-8230. https://doi.org/10.5194/acp-11-8215-2011

Penner, J.E., Ghan, S.J., Walton, J.J. (1991). The role of biomass burning in the budget and cycle of carbonaceous soot aerosols and their climate impact.

Priyadharshini, B., Verma, S., Chatterjee, A., Sharma, S.K., Mandal, T.K. (2019). Chemical characterization of fine atmospheric particles of water-soluble ions and carbonaceous species in a tropical urban atmosphere over the eastern Indo-Gangetic plain. Aerosol Air Qual. Res. 19, 129-147. https://doi.org/10.4209/aaqr.2017.12.0606

Putaud, J.P., Raes, F., Van Dingenen, R., Brüggemann, E., Facchini, M.C., Decesari, S., Fuzzi, S., Gehrig, R., Hüglin, C., Laj, P., Lorbeer, G., Maenhaut, W., Mihalopoulos, N., Müller, K., Querol, X., Rodriguez, S., Schneider, J., Spindler, G., Ten Brink, H., Tørseth, K., et al. (2004). A European aerosol phenomenology - 2: Chemical characteristics of particulate matter at kerbside, urban, rural and background sites in Europe. Atmos. Environ. 38, 2579-2595. https://doi.org/10.101 6/j.atmosenv.2004.01.041

Rai, A., Mukherjee, S., Chatterjee, A., Choudhary, N., Kotnala, G., Mandal, T.K., Sharma, S.K. (2020). Seasonal variation of OC, EC, and WSOC of $\mathrm{PM}_{10}$ and their CWT analysis over the eastern Himalaya. Aerosol Sci. Eng. 4, 26-40. https://doi.org/10.1007/s41810-020-00053-7

Rajput, P., Sarin, M., Kundu, S.S. (2013). Atmospheric particulate matter (PM2.5), EC, OC, WSOC and PAHs from NE-Himalaya: Abundances and chemical characteristics. Atmos. Pollut. Res. 4 214-221. https://doi.org/10.5094/APR.2013.022

Rajput, P., Sarin, M.M. (2014). Polar and non-polar organic aerosols from large-scale agriculturalwaste burning emissions in Northern India: Implications to organic mass-to-organic carbon ratio. Chemosphere 103, 74-79. https://doi.org/10.1016/j.chemosphere.2013.11.028

Rajput, P., Sarin, M.M., Sharma, D., Singh, D. (2014). Organic aerosols and inorganic species from post-harvest agricultural-waste burning emissions over northern India: Impact on mass absorption efficiency of elemental carbon. Environ. Sci. Process. Impacts 16, 2371-2379. https://doi.org/10.1039/c4em00307a

Rajput, P. (2018). OM/OC ratio of polar and non-polar organic matter during wintertime from Indo-Gangetic Plain: Implications to regional-scale radiative forcing. Aerosol Sci. Eng. 2, 153164. https://doi.org/10.1007/s41810-018-0032-6

Ram, K., Sarin, M.M. (2010). Spatio-temporal variability in atmospheric abundances of EC, OC and WSOC over Northern India. J. Aerosol Sci. 41, 88-98. https://doi.org/10.1016/j.jaerosci.2009. 11.004

Ram, K., Sarin, M.M., Tripathi, S.N. (2012). Temporal trends in atmospheric PM $2.5, \mathrm{PM}_{10}$, elemental carbon, organic carbon, water-soluble organic carbon, and optical properties: Impact of biomass burning emissions in the Indo-Gangetic Plain. Environ. Sci. Technol. 46, 686695. https://doi.org/10.1021/es202857w

Ramanathan, V., Crutzen, P.J., Lelieveld, J., Mitra, A.P., Althausen, D., Anderson, J., Andreae, M.O., 
Cantrell, W., Cass, G.R., Chung, C.E., Clarke, A.D., Coakley, J.A., Collins, W.D., Conant, W.C., Dulac, F., Heintzenberg, J., Heymsfield, A.J., Holben, B., Howell, S., Hudson, J., et al. (2001). Indian Ocean Experiment: An integrated analysis of the climate forcing and effects of the great Indo-Asian haze. J. Geophys. Res. 106, 28371-28398. https://doi.org/10.1029/2001JD900133

Rengarajan, R., Sarin, M.M., Sudheer, A.K. (2007). Carbonaceous and inorganic species in atmospheric aerosols during wintertime over urban and high-altitude sites in North India. J. Geophys. Res. 112, D21307. https://doi.org/10.1029/2006JD008150

Sahu, R.K., Pervez, S., Chow, J.C., Watson, J.G., Tiwari, S., Panicker, A.S., Chakrabarty, R.K., Pervez, Y.F. (2018). Temporal and spatial variations of $\mathrm{PM}_{2.5}$ organic and elemental carbon in Central India. Environ. Geochem. Health 40, 2205-2222. https://doi.org/10.1007/s10653-018-0093-0

Sannigrahi, P., Sullivan, A.P., Weber, R.J., Ingall, E.D. (2006). Characterization of water-soluble organic carbon in urban atmospheric aerosols using solid-state13C NMR spectroscopy. Environ. Sci. Technol. 40, 666-672. https://doi.org/10.1021/es051150i

Sawlani, R., Agnihotri, R., Sharma, C., Patra, P.K., Dimri, A.P., Ram, K., Verma, R.L. (2018). The severe Delhi SMOG of 2016: A case of delayed crop residue burning, coincident firecracker emissions, and atypical meteorology. Elsevier. https://doi.org/10.1016/j.apr.2018.12.015

Saxena, P., Hildemann, L.M. (1996). Water-soluble organics in atmospheric particles: A critical review of the literature and application of thermodynamics to identify candidate compounds. J. Atmos. Chem. 24, 57-109. https://doi.org/10.1007/BF00053823

Seinfeld, J., Pandis, S. (2016). Atmospheric chemistry and physics: From air pollution to climate change. Wiley.

Sharma, S.K., Mandal, T.K., Saxena, M., Rashmi, Sharma, A., Datta, A., Saud, T. (2014). Variation of OC, EC, WSIC and trace metals of PM10 in Delhi, India. J. Atmos. Sol.-Terr. Phys, 113, 10-22. https://doi.org/10.1016/j.jastp.2014.02.008

Sharma, S.K., Mandal, T.K., De, A.K., Deb, N.C., Jain, S., Saxena, M., Pal, S., Choudhuri, A.K., Saraswati (2018). Carbonaceous and inorganic species in PM10 during wintertime over Giridih, Jharkhand (India). J. Atmos. Chem. 75, 219-233. https://doi.org/10.1007/s10874-017-9373-9

Singh, N., Mhawish, A., Deboudt, K., Singh, R.S., Banerjee, T. (2017). Organic aerosols over IndoGangetic Plain: Sources, distributions and climatic implications. Atmos. Environ. 157, 59-74. https://doi.org/10.1016/j.atmosenv.2017.03.008

Singh, N., Banerjee, T., Raju, M.P., Deboudt, K., Sorek-Hamer, M., Singh, R.S., Mall, R.K. (2018). Aerosol chemistry, transport, and climatic implications during extreme biomass burning emissions over the Indo-Gangetic Plain. Atmos. Chem. Phys. 18, 14197-14215. https://doi.org/ 10.5194/acp-18-14197-2018

Singh, R., Kulshrestha, M.J., Kumar, B., Chandra, S. (2016). Impact of anthropogenic emissions and open biomass burning on carbonaceous aerosols in urban and rural environments of IndoGangetic Plain. Air Qual. Atmos. Health 9, 809-822. https://doi.org/10.1007/s11869-0150377-9

Sirois, A., Bottenheim, J.W. (1995). Use of backward trajectories to interpret the 5-year record of PAN and O"SUB 3" ambient air concentrations at Kejimkujik National Park, Nova Scotia. J. Geophys. Res. 100, 2867-2881. https://doi.org/10.1029/94JD02951

Snyder, D.C., Rutter, A.P., Collins, R., Worley, C., Schauer, J.J. (2009). Insights into the origin of water soluble organic carbon in atmospheric fine particulate matter. Aerosol Sci. Technol. 43, 1099-1107. https://doi.org/10.1080/02786820903188701

Srivastava, D., Tomaz, S., Favez, O., Lanzafame, G.M., Golly, B., Besombes, J.L., Alleman, L.Y., Jaffrezo, J.L., Jacob, V., Perraudin, E., Villenave, E., Albinet, A. (2018). Speciation of organic fraction does matter for source apportionment. Part 1: A one-year campaign in Grenoble (France). Sci. Total Environ. 624, 1598-1611. https://doi.org/10.1016/j.scitotenv.2017.12.135

Tiwari, R., Kulshrestha, U. (2019). Wintertime distribution and atmospheric interactions of reactive nitrogen species along the urban transect of Delhi - NCR. Atmos. Environ. 209, 40-53. https://doi.org/10.1016/j.atmosenv.2019.04.007

Tiwari, S., Pipal, A.S., Hopke, P.K., Bisht, D.S., Srivastava, A.K., Tiwari, Shani, Saxena, P.N., Khan, A.H., Pervez, S. (2015). Study of the carbonaceous aerosol and morphological analysis of fine particles along with their mixing state in Delhi, India: A case study. Environ. Sci. Pollut. Res. 22, 10744-10757. https://doi.org/10.1007/s11356-015-4272-6

Tiwari, S, Dumka, U.C., Kaskaoutis, D.G., Ram, K., Panicker, A.S., Srivastava, M.K., Tiwari, Shani, 
Attri, S.D., Soni, V.K., Pandey, A.K. (2016). Aerosol chemical characterization and role of carbonaceous aerosol on radiative effect over Varanasi in central Indo-Gangetic Plain. Atmos. Environ. 125, 437-449. https://doi.org/10.1016/j.atmosenv.2015.07.031

Turpin, B.J., Huntzicker, J.J. (1995). Identification of secondary organic aerosol episodes and quantitation of primary and secondary organic aerosol concentrations during SCAQS. Atmos. Environ. 29, 3527-3544. https://doi.org/10.1016/1352-2310(94)00276-Q 